\title{
Financial Development, Investment and Economic Growth: Evidence from Nigeria
}

\author{
Umar Bida Ndako ${ }^{\#}$
}

\author{
Monetary Policy Department, Central Bank of Nigeria, Abuja, Nigeria
}

\begin{abstract}
The paper evaluates the relationship among financial development, investment and economic growth in Nigeria. It also examines the role of investment in financial development and how it influences economic growth in Nigeria. The paper applies the standard Vector autoregression (VAR) framework of Johansen, the Inoue (1999) cointegration framework with endogenous structural break model and Johansen et al. (2000) cointegration test with exogenous structural breaks, respectively. After accounting for structural breaks in the series, the study establishes a long-run relationship among financial development, investment and economic growth. This indicates that failure to account for structural breaks in the series may lead to bias estimates and may mislead policy conclusion. It further reveals that investment is a critical channel that influences economic growth through financial development.
\end{abstract}

Keywords: Financial development, Investment, Economic growth, Structural breaks.

\section{INTRODUCTION}

Studies on financial development and economic growth are well documented in the literature. Schumpeter (1911), Patrick (1966), Goldsmith (1969), MacKinnon (1973), Shaw (1973), King and Levine (1993a and b) all argue that a well-developed financial system is important in stimulating economic growth. However, evidence from empirical studies has since contradicted these findings by obtaining results that are different across countries studied. This can be found in the work of Demetriades and Hussein (1996), Arestis and Demetriades (1997), Luintel and Khan (1999), Liang and Teng (2006), Ang and Mckibbin (2007), Masih et al. (2009), and Gries et al. (2009), Law and Singh (2014), Beck et al. (2014), Breitenlechner, et al. (2015), and Demetriades and Rousseau (2016).

The endogenous growth model has identified investment as one of the important channels linking financial development to economic growth (Pagano, 1993). Masih et al. (2009) explain that although there are no broad consensus on the number of channels, investment and/productivity are among the common channels often found in the literature. Benhabib and Spiegel (2000) have shown the positive impact of investment on economic growth through financial development. Xu (2000), using multivariate VAR tests on 41 countries obtains a result that strongly

${ }^{*}$ Address of correspondence to this author at the Monetary Policy Department Central Bank of Nigeria, Abuja, Nigeria; Tel: +2348164680258;

E-mail: ubndako@cbn.gov.ng

JEL Classification: C32, E22, E44, O16.

\#Umar Ndako is Principal Economist in the Monetary Policy Department, Central Bank of Nigeria. The views expressed in this paper by the Author do not in any way represent the official position of the Central Bank of Nigeria. supports the hypothesis that financial development promotes economic growth and concludes that investment is a key variable that helps to influence economic growth. Rousseau and Vuthipadadorn (2005) also obtain similar results for ten Asian countries using VAR technique. They show that investment is a critical channel influencing economic growth through financial development. Other studies that either control for the effect of investment or other economic variables include Chang and Caudill (2005), Atindehou et al. (2005), Liang and Teng (2006), Odhiambo (2007), Ang and Mckibbin (2007), Abu-Badr and Abu-Qarn (2008), Masih et al. (2009), Wolde-Rufael (2009), and Ndako (2010), Ogwumike and Salisu (2012). All these studies use the multivariate vector autoregression models and obtain different results across countries, particularly on the direction of causality. This is an indication that studies in this area still remain inconclusive.

This study, however, differs from the previous studies and thereby contributes to literature in the following two distinct ways: First, after Xu (2000) work on 41 countries that include Nigeria, this is the first major work that specifically focuses on financial development, investment and economic growth in Nigeria. Second, it differs from the work of Xu (2000) and other related works in Nigeria on the fact that it accounts for sudden changes both at the unit root and at the cointegration levels. For unit root test, it uses the endogenous structural break models of the Zivot and Andrew (1992) while for cointegration test; it is the first study to apply both the endogenous and exogenous structural break tests of Inoue (1999) and Johansen et al. (2000), respectively. Accounting for structural breaks in time series is very important, particularly in the less developed countries where financial and 
economic data are often susceptible to sudden changes. If structural breaks are not properly accounted for, they may lead to bias estimates thereby making the attainment of constant parameters in the estimate very difficult. Smith and Fraser (2003) show that parameter instability is clear evidence of model misspecification and without a constant parameter of the data generating process, it will be difficult to apply a meaningful economic theory. Thus, the paper attempts to fill this gap for the study of Nigeria by applying endogenous structural breaks both at unit root and at cointegrating levels.

The level of financial and economic reforms that has taken place over the last three decades has become one of the key reasons for the choice of Nigeria. The Nigerian financial system before 1986 was based on the policy of financial repression- fixed exchange rates, interest rate ceilings, selective credit control and government owned financial institutions. However, in 1986, the government introduced the Structural Adjustment Programme (SAP) and this paved way for the introduction of the liberalisation measures among which included privatisation of government owned financial institutions and deregulations of interest rates and exchange rates. This helped in opening up the domestic economy, increasing the level of investment and further deepening financial development and enhanced growth. Availability of time series data is another motivating factor.

The study applies multivariate vector autoregression model (VAR) with both endogenous and exogenous structural breaks. One important advantage of using a VAR model is that it treats all variables in the model as endogenous. It has also been shown to be a powerful tool for forecasting (Asteriou and Hall, 2007). The paper uses two proxies of financial development: Domestic Credit to the Private sector (DCP) and Broad Money (LM2). The choice of these proxies is based on the fact that the entire financial system in Nigeria and other sub-Saharan Africa countries is dominated mainly by the banking sector (World Bank, 2007). These proxies have also been used in many works including the recent works by Law and Singh (2014), Beck et al. (2014), and Demetriades and Rousseau (2016). After accounting for structural breaks in the series, the paper establishes a cointegration relationship among financial development, investment and economic growth. It also explains the important role of investment as critical channel in financial development.
Although macro econometric models do have their limitations in terms of applications to policy issues, they can, however, be very useful to decision policy makers especially in the analysis of consequences or causes and effects of different policy options (Don, 2004,). Therefore, it can be stated that not all models can provide answers to all policy questions because of the inherent limitations in them. However, the models used and the results obtained in this study can be quite relevant not only to policy makers but investors, bankers and entrepreneurs as it will avail them the opportunity to better understand the overall investment climate in Nigeria and the implications for financial development and economic growth.

The paper is organised into five sections: section one is the introduction. Section two discusses the theoretical framework. Section three presents data and econometric methodology. The empirical result of the study is presented in section four while section five presents the conclusion of the paper.

\section{THEORY}

The body of literature in recent years that recognized the positive role of financial intermediaries in the growth process is based on the endogenous growth model. The model improves on the earlier works of McKinnon (1973) and Shaw (1973) hypothesis. ${ }^{1}$ The main feature of the financial endogenous growth model is the incorporation of the role of financial system in the growth process. Those that formalized and popularized endogenous growth models and showed that financial development promotes economic growth include Fry (1988), Greenwood and Jovanovic (1990), Pagano (1993), Bencivinga and Smith (1991), Berthelemy and Varoudakis (1996) and Blackburn et al. (2005). Greenwood and Jovanovic (1990) explain that efficient management of information on the competing technologies of production and resources can be channelled to the most productive sector of the economy, which in turn promotes economic growth. Bencivenga and Smith (1991) on the other hand, show that an efficient financial intermediary can manage risks, ensures flow of information and effectively engages in maturity transformation. All this effectively

\footnotetext{
${ }^{1}$ The main idea of McKinnon-Shaw (1973) hypothesis is that control of financial system by the government may prevent economic growth in developing countries. Therefore, the only way rapid economic growth can be achieved is to allow the markets to direct the activities of financial system which is termed financial liberalization.
} 
helps in resource allocation and promotes economic growth. Berthelemy and Varoudakis (1996) also demonstrate through a multiple steady-equilibrium how positive externality between the financial intermediaries and the productive sector of the economy lead to increase saving and economic growth. Blackburn et al. (2005) present a model that is based on financial structure where both banks and stock markets are jointly determined, using overlapping generation model. In the earlier models financial intermediation either takes the form of banking or stock market but not both. However, this model can accommodate either banking or stock market variables or a combination of both. Pagano (1993), through A.K. production model explains how the role of financial intermediaries is incorporated in the growth model and this can be through a fraction saving to investment, marginal productivity of capital and private saving.

\section{DATA AND ECONOMETRIC METHODOLOGY}

The paper uses annual data from 1960-2014 of four variables: Gross Domestic Product per capita (GDP), Investment (INV), and financial development represented by Domestic Credit Private sector (DCP), and Broad Money (LM2) which are all transformed into logarithms. All data are sourced from the World Development Indicators (2016) except Investment (Gross fixed Capital formation) which was sourced from Central Bank of Nigeria (2016).

The econometric specification of the paper starts with the unit root tests. This is followed by the Johansen $(1988,1992)$ cointegration test and the Inoue (1999) rank test with endogenous structural breaks. A robustness test of cointegration is also carried out, using the Johansen et al. (2000) test with exogenous structural breaks. Three types of unit root tests are performed in this paper, which are Augmented DickeyFuller (ADF), and Dickey-Fuller GLS (DF-GLS) Zivot and Andrews (ZA) unit root tests, respectively. Evidence has shown that the conventional unit root tests, particularly the ADF test is subject to lower power and size distortion problems. Both Perron (1989), Zivot and Andrews (1992), as well as Perron and Vogelsang (1992) explain that time series data do exhibit sudden changes which might be due to economic, financial or political events. Therefore, relying on conventional unit root tests for series that contain a sudden change may lead to bias estimates. Perron (1989) develops a model that allows a unit root test with exogenous structural breaks that is with a known break date. However, Zivot and Andrews (1992) developed an alternative approach to the Perron (1989) model that allows for a unit root test with endogenous breaks with unknown break dates. The Zivot and Andrew's (1992) model is based on three models. Model A accommodates a break point at the level of the data; Model B captures the structural break point in the slope, while Model $C$ is for both changes in the level and in the trend of the series.

\subsection{Structural Break at Cointegration Level}

Once a structural break has been identified at unit root level, it has implications for estimation of cointegration and thus, using the standard Johansen technique would not be appropriate, (Chen at al. 2009). Inoue (1999) also points out that the presence of structural breaks in a cointegrated framework may produce a misleading result by accepting a null hypothesis of no cointegration or null of a cointegrating rank that may be less than its true rank as in the case of residual based test of Perron (1989) and Johansen (1988) test.

This study follows the work of Inoue (1999) by endogenously identifying structural breaks in a cointegrated framework. The framework is similar to the standard Johansen cointegration technique of maximum likelihood. It is, however, based on three models: $A, B$ and $C$, respectively. Model A presents a possible break in the mean, while the break in the trend is presented by Model B. Model C estimates both breaks in the mean and in the trend. The model is sequentially estimated by incorporating step dummies to allow for possible breaks. It locates the break points using the relative size of eigenvalues obtained from the estimates.

The method has been shown to be superior to the residual-based test of Gregory and Hansen (1996), which pre-determined the break dates or exogenously select the break points. (Chen et al. 2009)

The model is specified below:

$$
\begin{aligned}
& Y_{t}^{i}\left(\xi_{0}\right)=\sum_{j=1}^{p} \phi_{j} Y_{t-j}^{i}\left(\xi_{0}\right)+u_{t}, i=A, B, \\
& Y_{t}^{A}(\xi)=X_{t}-\mu-\tilde{\mu} D U_{t}(\xi), \\
& Y_{t}^{B}(\xi)=X_{t}-\mu-\tilde{\mu} D U_{t}(\xi)-\delta_{t}-\tilde{\delta} D T_{t}(\xi), \\
& Y_{t}^{C}=c+\tilde{\mu} D U_{t}\left(\xi_{0}\right)+\sum_{j=1}^{P} \phi_{j} Y_{t-j}^{C}+u_{t}, Y_{t}^{C}=X_{t},
\end{aligned}
$$


Where $X_{t}$ is the original data series at time $t$; $\left\{\phi_{j}\right\}_{j=1}^{P}$ are $n \times n$ matrices and $u_{t} \sim N I D\left(0_{n \times 1}, \Omega\right)$. $X_{t}, \mu, \tilde{\mu}, \delta$ and $\tilde{\delta}$ are $n$-dimensional vectors; dummy variables are $D U_{t}(\xi)$ and $D T_{t}(\xi)$ are specified as follows:

$D U_{t}(\xi)=\left\{\begin{array}{ll}0, & t<[T \xi] \\ 1, & t \geq[T \xi]\end{array} \quad D U_{t}(\xi)= \begin{cases}0, & t<[T \xi] \\ (t-[T \xi]+1), & t \geq[T \xi]\end{cases}\right.$

The three above models $(i=A, B, C)$ can also be expressed in error- corrected form:

$\Delta Y_{t}^{i}(\xi)=\Pi Y_{t}^{i}(\xi)+\sum_{j=1}^{P-1} \Gamma_{j} \Delta Y_{t-j}^{i}+u_{t} i=A, B$,

$\Delta Y_{t}^{C}=c+\tilde{\mu} D U_{t}(\xi)+\Pi Y_{t-1}^{C}+\sum_{j=1}^{P-1} \Gamma_{j} \Delta Y_{t-j}^{C}+u_{t}$

Where $\alpha$ and $\beta$ are $n \times q$ matrices in such a way that $\alpha \beta^{\prime}=\Pi ;\left\{\phi_{j}\right\}_{j=1}^{P-1}$ and $\Pi$ are $n \times n$ matrices, showing the adjustment and long-run components, respectively while, $u_{t} \sim N\left(0_{n \times 1}, \Omega\right)$.

To examine the test of hypothesis, Inoue (1999) uses both trace and maximum eigenvalues tests which are similar to Johansen $(1988,1992)$ framework. The null hypothesis is stated as follows:

$H_{0}: \operatorname{rank}(\alpha)=\operatorname{rank}(\beta) \leq r, \tilde{\mu}=\delta=0_{n \times 1}$

$H_{1}: \operatorname{rank}(\alpha)=\operatorname{rank}(\beta)>r$

Where $0 \leq r \leq q$ and $r<n$, using the trace test statistic

$\sup _{\xi \in \Xi}\left\{-T \sum_{j=r+1}^{T} \ln \left(1-\hat{\lambda}_{j}^{i}(\xi)\right)\right\}$

The above null hypothesis can also be tested against the alternative

$H_{2}$ : rank $(\alpha)=\operatorname{rank}(\beta)=r+1$. using the maximum eigenvalues statistic.

$\sup _{\xi \in \Xi}\left\{-T \ln \left(1-\tilde{\lambda}_{r+1}^{i}(\xi)\right)\right\}$

The study also applies the exogenous structural breaks model of Johansen et al. (2000). The essence is to use the break points identified by Inoue's model and incorporate them into the trace tests of the Johansen et al. (2000) and then estimate the relationship among financial development, investment and economic growth. Johansen et al. (2000) considered two types of trace tests for cointegration. The linear trend $H l(r)$ and a constant level $H c(r)$ where there are $(q-1)$ breaks with $q$ representing the sub-sample, which could be in the linear trend or in a constant level of the total sample data. The likelihood ratio test statistics are specified as follows:

$$
\begin{aligned}
& L R\left\{H_{l}(r) \backslash H_{l}(P)\right\}=-T \sum_{i=r+1}^{P} \log \left(1-\hat{\lambda}_{l i}\right) \\
& L R\left\{H_{c}(r) \backslash H_{c}(P)\right\}=-T \sum_{i=r+1}^{P} \log \left(1-\hat{\lambda}_{c i}\right)
\end{aligned}
$$

Where $\hat{\lambda}_{c i}$ correspond to the values of the canonical correlations for the regressors in the broken constant level model.

\section{EMPIRICAL RESULTS}

The unit root tests are presented in Table 1 and are based on the conventional ADF and DF-GLS tests. Evidence from the Table suggests that all the four series in the study are integrated of order I (1), indicating that all the four series at levels are nonstationary but at first difference they become stationary. The endogenous structural break test of Zivot and Andrews's unit root test is presented in Table 2. Evidence from the Table indicates structural breaks and non-stationary behaviour in all the four series. This result is consistent with the ADF and DF-GLS tests, respectively. The break dates at unit root level are 1984, 1987, and 2009, respectively.

Table 3 (Model A) presents the standard Johansen cointegration rank test and it comprises Economic Growth, (LGDP), Domestic Credit to Private sector (LDCP) and Investment (LINV). The result shows no evidence of any long-run relationship among financial development, investment and economic growth. Based on this result, it means that these series over time do not share any common stochastic trend. To ensure that appropriate lags are selected for which there is no presence of serial correlation, the study employs the Schwarz Information Criterion (SIC), the Akaike Information Criterion (AIC) and the Final Prediction Error (FPE), respectively. All the lags selection criteria suggest the use of lag order two except the SIC that selects lag order one. For a robustness test, the study uses another measure of financial development, Broad Money (LM2) as indicated by model B in Table 4. The result also indicates presence of no cointegration 
Table 1: Unit Root Tests

\begin{tabular}{|c|c|c|c|c|}
\hline Level & \multicolumn{3}{|c|}{ First Difference } \\
\hline variable & ADF & DF-GLS & ADF & DF-GLS \\
\hline \hline LGDP & -0.496 & -0.235 & $-5.225^{*}$ & $-5.156^{*}$ \\
LDPC & -2.478 & -1.177 & $-6.487^{*}$ & $-6.549^{*}$ \\
LM2 & -2.609 & -1.314 & $-5.924^{*}$ & $-5.981^{*}$ \\
LINV & 0.036 & 0.839 & $-4.284^{*}$ & $-3.830^{* *}$ \\
\hline
\end{tabular}

Note: Asterisks * and ** are $5 \%$ and $1 \%$ levels of significance, respectively.

Table 2: Unit Root Tests of Zivot-Andrews

\begin{tabular}{|c|c|c|c|}
\hline Variable & Model & Break dates & Critical value \\
\hline \hline LGDPPC & C & 1987 & -5.794 \\
LDCP & C & 2009 & -8.071 \\
LM2 & C & 2009 & -6.666 \\
LINV & A & 1984 & -4.778 \\
\hline
\end{tabular}

Note: The Critical values obtained from Zivot-Andrews (1992) are -4.58 and -4.80 for models A and B while for model C are -4.82 and -5.08 , respectively.

among the variables. The lag selection criteria also selected lag order two. Evidence from the Lagrange multiplier (LM) tests for the two models indicate absence of serial correlation in the series at lag 2 with corresponding $p$-values of 0.1872 and 0.1771 , respectively.

The Inoue's rank cointegration tests with endogenous structural break model are shown in Tables $\mathbf{5}$ and $\mathbf{6}$, respectively. The results indicate the presence of at least one cointegration in the two models and are statistically significant at $5 \%$. The Inoue's technique finds significant break points which are 2009, 2006 and 1987 using the three models of $A$, $B$ and $C$, respectively. However, in this paper, we used the break date identified by Model B as recommended by Inoue for trend break with unknown dates. The break dates identified by Model B mostly occur during 2009. The period coincided with global financial crisis of 2008-2009. In Nigeria, the period was characterized by rise in bad debts. This was partly explained by the Nigerian banks' exposure to lending for investment in stocks, oil and gas and when the bubble burst the NonPerforming Loans (NPL) ratio was very high, leading to bank bailouts by the Central Bank of Nigeria in 2009. In

Table 3: Model A: Johansen Rank Test = (LGDP, LDCP, LINV)

\begin{tabular}{|c|c|c|c|c|c|}
\hline Ho & H1 & $\lambda$ Trace & 95\% critical value & $\lambda$ max & 95\% critical value \\
\hline \hline$r=0$ & $r \geq 1$ & 22.340 & 29.797 & 15.31 & 21.131 \\
\hline$r \leq 1$ & $r \geq 2$ & 7.025 & 15.494 & 5.880 & 14.264 \\
\hline$r \leq 2$ & $r=3$ & 1.145 & 3.841 & 1.145 & 3.841 \\
\hline
\end{tabular}

Note: number of cointegrating vector is indicated by $r$ while ${ }^{*}$ and ${ }^{* *}$ are $1 \%$ and $5 \%$ levels statistical significance, respectively. LGDP, LDCP and LINV stand for Gross Domestic Product, Financial development and Investment.

Table 4: Model B: Johansen Rank Test = (LGDP, LM2, LINV)

\begin{tabular}{|c|c|c|c|c|c|}
\hline Ho & H1 & $\lambda$ Trace & 95\% Critical value & $\lambda$ max & 95\% critical value \\
\hline \hline$r=0$ & $r \geq 1$ & 20.881 & 29.797 & 15.239 & 21.131 \\
$r \leq 1$ & $r \geq 2$ & 5.642 & 15.494 & 4.614 & 14.264 \\
$r \leq 2$ & $r=3$ & 3.028 & 1.028 & 3.841 \\
\hline
\end{tabular}

Note: number of cointegrating vector is indicated by $r$ while ${ }^{*}$ and ${ }^{* *}$ are $1 \%$ and $5 \%$ levels statistical significance, respectively. LGDP, LM2 and LINV stand for Gross Domestic Product, Financial development and Investment. 
Table 5: Inoue Rank Test for Model A: (LGDP, LDCP, LINV)

\begin{tabular}{|c|c|c|c|c|c|c|}
\hline \multirow{2}{*}{ Ho } & \multicolumn{2}{|c|}{ Model A } & \multicolumn{2}{|c|}{ Model B } & \multicolumn{2}{|c|}{ Model C } \\
\hline & $\lambda$ Trace & $\lambda \operatorname{Max}$ & $\lambda$ Trace & $\lambda \operatorname{Max}$ & $\lambda$ Trace & $\lambda \operatorname{Max}$ \\
\hline$r=0$ & $\begin{array}{c}38.535^{\star *} \\
(2006)\end{array}$ & $\begin{array}{c}29.126^{\star *} \\
(2009)\end{array}$ & $\begin{array}{c}35.676^{* *} \\
(2009)\end{array}$ & $\begin{array}{c}30.182^{* *} \\
(2009)\end{array}$ & $43.725^{\star}$ & $\begin{array}{c}36.117^{\star *} \\
(1987)\end{array}$ \\
\hline$r \leq 1$ & 9.179 & 8.766 & 8.517 & 6.664 & 13.856 & 10.516 \\
\hline$r \leq 2$ & 3.517 & 3.379 & 1.815 & 1.902 & 3.472 & 2.617 \\
\hline
\end{tabular}

Critical values are obtained from Inoue (1999) Journal of Econometrics 90, pp. 215-237. The break points are in parenthesis while * and ** represent the rejection at $1 \%$ and $5 \%$ level of significance, respectively. Sequential LR tests were used to obtain the lag order.

Table 6: Inoue Rank Test for Model B: (LGDP, LM2, LINV)

\begin{tabular}{|c|c|c|c|c|c|c|}
\hline \multirow{2}{*}{ Ho } & \multicolumn{2}{|c|}{ Model A } & \multicolumn{2}{|c|}{ Model B } & \multicolumn{2}{|c|}{ Model C } \\
\hline & $\lambda$ Trace & $\lambda \operatorname{Max}$ & $\lambda$ Trace & $\lambda \operatorname{Max}$ & $\lambda$ Trace & $\lambda \operatorname{Max}$ \\
\hline$r=0$ & $\begin{array}{c}48.212^{*} \\
(1984)\end{array}$ & $\begin{array}{c}37.417^{* *} \\
(1987)\end{array}$ & $\begin{array}{c}55.672^{*} \\
(2001)\end{array}$ & $\begin{array}{l}31.462 \\
(1987)\end{array}$ & $53.725^{\star}$ & $\begin{array}{c}48.883^{*} \\
(1987)\end{array}$ \\
\hline$r \leq 1$ & 11.315 & 9.821 & 15.354 & 13.936 & 10.222 & 10.034 \\
\hline$r \leq 2$ & 2.752 & 1.017 & 1.234 & 1.018 & 3.014 & 1.009 \\
\hline
\end{tabular}

Critical values are obtained from Inoue (1999), Journal of Econometrics 90, pp. 215-237. The break points are in parenthesis while * and ** represent the rejection at $1 \%$ and $5 \%$ level of significance, respectively. Sequential LR tests were used to obtain the lag order.

the second model (LGDP, LM2, LINV), we used 1987 break date since it is the most common date identified by the endogenous break point of Inoue (1999). 1987 coincided with period Nigeria deregulated the interest rate following the introduction of Structural Adjustment Programme (SAP) in June 1986. It was also the period the Central Bank granted new license for the establishment of new commercial and merchant banks.

Evidence from Tables $\mathbf{5}$ and $\mathbf{6}$ means that lack of cointegration in using the standard VAR model (in Table 4 and 5 ) is due the presence of structural breaks in the series. Therefore, ignoring structural breaks may lead to a misleading and bias policy conclusion.

For robustness test, the paper used the break dates (2009 and 1987 for both models A and B, respectively) identified by the Inoue rank test to estimate the trace test of Johansen et al. (2000), which is shown Table 7.2 Evidence from the results suggests the presence of a long-run relationship among financial development, investment and economic growth for both models $A$

\footnotetext{
${ }^{2}$ The Johansen et al. (2000) estimates the cointegration rank in the presence of sudden changes. The break points are exogenously selected by dividing the total sample $T$ in to q sub sample periods. However, it should be noted that parameters for a given gamma distribution vary according to the number of observations and the location of break points. (Giles and Godwin, 2012) In this study, the total number of observation is 55 with a sing break point (q2), i.e. $v=$ $\mathrm{T} 1 / \mathrm{T} 2=0.91$ for Model $\mathrm{A}$ and 0.51 for Model $\mathrm{B}$. Critical values are obtained from the work of Giles and Godwin (2012).
}

and $\mathrm{B}$, respectively. This makes it consistent with the Inoue's rank cointegration test. Therefore, in the presence of structural breaks, using standard Johansen VAR may not be appropriate. This is because it may reveal that there is no cointegration (as shown in Tables 3 and 4) while in the actual fact cointegration does exist.

Table 8 presents the long-run coefficient of the cointegrating vectors for both models $A$ and $B$, respectively. Since there is only one cointegration identified by Inoue (1999) rank test for the two models, we simply normalized on GDP. In model A, the GDP is positively related with financial development and investment which makes it consistent with the endogenous growth model. This means that investment is an important channel that influences economic growth through financial development as shown in the endogenous growth model of Pagano (1993). The loading factor has the right sign, negative and statistically significant at $10 \%$, making it consistent with Wickens (1996) that for a loading factor to be meaningful, it must be negative and statically significant. In model $B$, the result is also consistent with model $\mathrm{A}$ as both financial development (represented by LM2) and investment are statistically significant at $1 \%$. The loading adjustment is also significant at $10 \%$ and it is negative. 
Table 7: Johansen et al. (2000) Trace test

\begin{tabular}{|c|c|c|c|c|c|}
\hline \multicolumn{2}{|c|}{ Model A } & \multicolumn{2}{c|}{ Model B } \\
\hline Ho & $\lambda$ Trace & $\mathbf{9 5 \%}$ & Ho & \multicolumn{2}{c|}{$\lambda$ Trace } \\
\hline \hline$r \leq 0$ & 40.61 & 42.91 & $r \leq 0$ & 41.20 & 29.79 \\
$r \leq 1$ & 5.461 & 25.87 & $r \leq 1$ & 0.827 & 15.49 \\
$r \leq 2$ & 0.286 & 12.51 & $r \leq 2$ & 0.517 & 3.841 \\
\hline
\end{tabular}

Critical values are obtained from Giles and Godwin (2012) distribution based on the break on linear trend i.e. $H l(r)$ trace test.

Table 8: Coefficient of the Long-Run Cointegrating Vector

\begin{tabular}{|c|c|c|c|c|c|c|}
\hline Model A & LGDP & constant & LDCP & LINV & DM & loading factor $(\alpha)$ \\
\hline \hline & 1 & 874.2 & $\begin{array}{c}+153.1^{* * *} \\
(4.428)\end{array}$ & $\begin{array}{c}+80.75^{* * *} \\
(7.048)\end{array}$ & $\begin{array}{c}-18.51^{* * *} \\
(-3.848)\end{array}$ & $\begin{array}{c}-0.036^{*} \\
(-1.547)\end{array}$ \\
\hline Model B & LGDP & constant & LM2 & LINV & DM & loading factor $(\alpha)$ \\
\hline \hline & 1 & 640.1 & $+67.77^{* * *}$ & $\begin{array}{c}+59.05^{* \star *} \\
(3.090)\end{array}$ & $\begin{array}{c}-12.88^{* * *} \\
(2.916)\end{array}$ & $\begin{array}{c}-0.024 \\
(-1.762)\end{array}$ \\
\hline
\end{tabular}

Note: $\left(^{(* *}\right)$, and $\left(^{*}\right)$ are $1 \%$ and $10 \%$ level of statistical significance. t- Values are in parentheses while DM represents a dummy variable.

The long-run causality or the weak exogeneity test is presented in Table 9, using the chi-square distribution and the probability values, respectively. Evidence from Model A shows bi-directional causality between financial development and economic growth. The same bi-directional causality is also obtained between investment and economic growth, investment and financial development. However, unidirectional causality is obtained from economic growth to financial development, using Model B. Unidirectional causality is also established from investment to financial development. The relationship between investment and economic growth is however, bi-directional.

Table 9: Weak Exogeneity/Long-Run Causality Tests

\begin{tabular}{|c|c|}
\hline Model A: (LGDP, LDCP LINV) & Model B: (LGDP, LM2,LINV) \\
\hline \hline LGDP (Ho: $\left.a_{11}=0\right)$ & LGDP (Ho: $\left.a_{11}=0\right)$ \\
\hline$x^{2}(1): 1.827$ & $x^{2}(1): 4.533$ \\
P. Value: $0.0167^{* *}$ & P. Value: $0.033^{* *}$ \\
\hline LINV (Ho: $\left.a_{21}=0\right)$ & LINV (Ho: $\left.a_{21}=0\right)$ \\
\hline$x^{2}(1): 7.229$ & $x^{2}(1): 8.342$ \\
P. Value: $0.0072^{*}$ & P. Value: $0.0038^{*}$ \\
\hline LDCP (Ho: $\left.a_{31}=0\right)$ & LM2 (Ho: $\left.a_{31}=0\right)$ \\
\hline $\begin{array}{c}x^{2}(1): 9.882 \\
\text { P. Value: } 0.0017^{*}\end{array}$ & $\begin{array}{c}x^{2}(1): 0.353 \\
\text { P. Value: } 0.5520\end{array}$ \\
\hline
\end{tabular}

Note: $\left({ }^{*}\right)$ and $\left({ }^{* *}\right)$ indicate $1 \%$ and $5 \%$ levels of significance, respectively.

\section{CONCLUSION}

The relationship among financial development, investment and economic growth is examined in this paper. The essence is to explain whether investment is a critical channel through which financial development influences economic growth. The paper uses the standard Vector autoregression (VAR) framework of Johansen, the Inoue (1999) cointegration with endogenous break model and the trace test of Johansen et al. (2000) of cointegration with exogenous structural breaks, respectively. After applying the standard VAR model, the study could not establish any presence of cointegration. However, after accounting for structural breaks in the series, using the endogenous model of Inoue rank test, the study established one cointegrating vector in both model $A$ and model $B$, respectively. The study also revealed that investment is a key channel that influences economic growth through financial development. This finding is consistent with the endogenous growth model of Pagano (1993). It is also consistent with the empirical findings of $\mathrm{Xu}$ (2000). The implication of these findings for a developing country like Nigeria is that investment is a critical factor through which financial development impacts on economic growth. Therefore, adequately enabling environment followed by appropriate financial and economic reforms that would promote both domestic and foreign investments must be in place, otherwise the role of finance in promoting economic growth would continue to be limited. 


\section{REFERENCES}

Abu-Badr and Abu-Qarn, 2008. "Financial Development and Economic Growth: The Egyptian Experience", Journal of Policy Modelling, 30: 887-898. https://doi.org/10.1016/j.jpolmod.2007.02.001

Ang, J. B. and McKibbin W. J., 2007. "Financial Liberalization, Financial Sector Development and Growth", Evidence From Malaysia, Journal of Development Economics, 84 (1): 215233.

https://doi.org/10.1016/j.jdeveco.2006.11.006

Arestis, P. and Demetriades, P., 1997. "Financial Development and Economic Growth: Assessing the Evidence," The Economic Journal, 107(442): 783-799. https://doi.org/10.1111/j.1468-0297.1997.tb00043.x

Asteriou, D. and Hall S.G., 2007. "Applied Econometrics: A Modern Approach Using Eviews and Microfit", NewYork, Palgrave Macmillan.

Atindehou, R. B. Gueyie J. P. and Amenounve E. K., 2005. "Financial Intermediation and Economic Growth: evidence from West Africa," Applied Financial Economics, 15(11): 777-790. https://doi.org/10.1080/09603100500108030

Beck, R., Georgiadis, G., Straub, R., 2014. The Finance and Growth Nexus Revisited. Economics Letters 124 (3): 382-385. https://doi.org/10.1016/j.econlet.2014.06.024

Bencivenga, V. R., and Smith, B. D. 1991., "Financial Intermediation and Endogenous Growth," Review of Economic Studies, 58 (2): 195-209. https://doi.org/10.2307/2297964

Benhabib, J.and Mark M. Spiegel, M.M., 2000. "The Role of Financial Development in Growth and Investment," Journal of Economic Growth, 5 (4): 341-360. https://doi.org/10.1023/A:1026599402490

Berthelemy, J. and Varoudakis, A., 1996. "Economic Growth, Convergence Clubs, and the Role of Financial Development," Oxford Economic Papers, 48(2): 300-328. https://doi.org/10.1093/oxfordjournals.oep.a028570

Blackburn, K., Bose, N., and Capasso S., 2005. "Financial Development, Financing Choice and Economic Growth", Review of Development Economics, 9: 135-149. https://doi.org/10.1111/j.1467-9361.2005.00268.x

Breitenlechner, C, Gächter, M. and Sindermann, F., 2015. "The Finance-Growth Nexus in crisis" Economics Letters 132: 3133.

https://doi.org/10.1016/j.econlet.2015.04.014

Chang, T. and Caudil, S. B., 2005. "Financial Development and Economic Growth: The Case of Taiwan," Applied Economics, 37(12):1329-1335 https://doi.org/10.1080/0003684042000338702

Chen, C.W.S; Grlach, R; Cheng N.Y.P. and Yang Y.L., 2009. "The Impact of Structural Breaks On The Integration of the ASEAN-5 Stock Markets" Mathematics and Computer in Simulation 79: 2654-2664. https://doi.org/10.1016/j.matcom.2008.12.012

Demetriades, P. O. and Hussein, K. A., 1996. "Does Financial Development Cause Economic Growth?" Time Series Evidence from 16 Countries" Journal of Development Economics 51, (2): 387-411. https://doi.org/10.1016/S0304-3878(96)00421-X

Demetriades, P.O and Peter L. Rousseau, P. L., 2016. "The Changing Face of Financial Development" Economics Letters 141: 87-90. https://doi.org/10.1016/j.econlet.2016.02.009

Don, F.J.H, 2004. "How Econometric Models Help Policy Makers: Theory and Practice" De Economist: 152, (2): 177-195. https://doi.org/10.1023/B:ECOT.0000023255.42322.d7
Fry, M. J., 1988. "Money, Interest, and Banking in Economic Development," John Hopkins University Press, Johns Hopkins Studies in Development series Baltimore and London.

Giles D. E and Godwin R. T., 2012. "Testing for Multivariate Cointegration in the Presence of Structural Breaks: $p$-Values and Critical Values" Applied Economics Letters 19: 15611565. https://doi.org/10.1080/13504851.2011.639727

Goldsmith, R. W., 1969. "Financial Structure and Development", New Haven, CT: Yale University Press.

Gregory, A. and Hansen B., 1996. 'Residual-Based Tests for Cointegration In Models with Regime Shifts', Journal of Econometrics, 70: 99-126. https://doi.org/10.1016/0304-4076(69)41685-7

Gries, T., M. Kraft and Meierrieks D., 2009. "Linkages between Financial Deepening, Trade Openness and Economic Development: Causality Evidence from Sub-Saharan Africa." World Development 37: 1849-1860. https://doi.org/10.1016/j.worlddev.2009.05.008

Greenwood, J. and Jovanovic, B., 1990. "Financial Development, Growth, and the Distribution of Income," The Journal of Political Economy, 98 (5):1076-1107. https://doi.org/10.1086/261720

Inoue A., 1999. "Tests Of Cointegrating Rank with A Trend-Break" Journal of Econometrics 90: 215-237. https://doi.org/10.1016/S0304-4076(98)00042-6

Johansen, S., 1988. "Statistical Analysis of Cointegration Vector," Journal of Economic Dynamics and Control, 12(2): 231-254. https://doi.org/10.1016/0165-1889(88)90041-3

Johansen, S. and Katarina, J., 1992. "Testing Structural Hypothesis in a Multivariate Cointegration Analysis of the PPP and UIP for UK," Journal of Econometrics, 53(1): 211-244. https://doi.org/10.1016/0304-4076(92)90086-7

Johansen, S., Mosconi, R. and Nielsen B., 2000. Cointegration Analysis in the Presence of Structural Breaks in the Deterministic Trend, Econometrics Journal, 3: 216-249. https://doi.org/10.1111/1368-423X.00047

King, R. G. and Levine, R., 1993a. "Finance and Growth Schumpeter Might be Right," The Quarterly journal of Economics, 108 (3): 717-737. https://doi.org/10.2307/2118406

King, R. G. and Levine. R., 1993b. "Finance, Entrepreneurship, and Growth. Theory and Evidence," Journal of monetary Economics, 32(3): 512-542. https://doi.org/10.1016/0304-3932(93)90028-E

Law S.H. and Singh, N., 2014. "Does Too Much Finance Harm Economic Growth?" Journal of Banking \& Finance 41: 36-44. https://doi.org/10.1016/j.jbankfin.2013.12.020

Liang, Q. and Teng J-Z., 2006. "Financial Development and Economic Growth: Evidence from China", China Economic Review, 17: 395- 411. https://doi.org/10.1016/j.chieco.2005.09.003

Luitel, K. B. and Khan M., 1999. "A Quantitative Reassessment of the Finance-Growth Nexus: Evidence from a Multivariate VAR," Journal of Development Economics, 60 (2): 381-405. https://doi.org/10.1016/S0304-3878(99)00045-0

MacKinnon, R. I. (1973), "Money and Capital In Economic Development" Washington, DC: Brookings Institution.

Masih, M. A. A. and Haider. M., 2009. "Causality between Financial Development and Economic Growth: an Application of Vector Error Correction and Variance Decomposition Methods to Saudi Arabia," Applied Economics, 41(13): 1691-1699. https://doi.org/10.1080/00036840701320233

Ndako, U. B., 2010. "Financial Development and Economic Growth: Evidence from Nigeria" The IUP Journal of Financial Economics, 8(4): 37-58. 
Odhiambo, N. M., 2007. "Supply-Leading Versus Demand-Following Hypothesis: Empirical Evidence from Three SSA Countries," African Development Review, 19(2): 257-280. https://doi.org/10.1111/j.1467-8268.2007.00161.x

Ogwumike, Fidelis O, and Salisu, A., 2012. Financial Development and Economic Growth in Nigeria Journal of Monetary and economic Integration, Vol. 12 (2): 92-1119.

Pagano, M., 1993. "Financial Markets and Growth: An overview," European Economic Review, 37 (2-3): 613-622. https://doi.org/10.1016/0014-2921(93)90051-B

Patrick, H. T., 1966. "Financial Development and Economic Growth in Undeveloped Countries," Economic Development and Cultural Change, 14 (2): 429-447. https://doi.org/10.1086/450153

Perron, P. 1989. The Great Crash, the Oil Price Shock and the Unit Root Hypothesis, Econometrica, 57: 1361-1401. https://doi.org/10.2307/1913712

Perron, P. and Vogelsang T.J., 1992. Nonstationarity and Level Shifts with an Application to Purchasing Power Parity, Journal of Business and Economic Statistics, 10: 301-320. https://doi.org/10.1080/07350015.1992.10509907

Rousseau, P.L and Vuthipadadorn D. 2005. "Finance, Investment, and Growth: Time series Evidence from 10 Asian Economies" Journal of Macroeconomics 27: 87-106. https://doi.org/10.1016/j.jmacro.2003.09.004
Schumpeter, J. A., 1911. "The Theory of Economic Development" Cambridge, MA: Harvard University Press.

Shaw, E. S., 1973. "Financial Deepening in Economic Development" New York: Oxford University Press.

Smith D.R. and Fraser S. 2003. "Structural breaks in $\mathrm{GARCH}$ models" Accessible at: http://www.fsa.ulaval.ca/nfa2003/ papiers/Daniel\%20Smith.pdf

Wickens, M. R. 1996. "Interpreting Cointegrating Vectors and Common Stochastic Trend." Journal Of Econometrics, 74(2): 255-271. https://doi.org/10.1016/0304-4076(95)01746-1

Wolde-Rufael, Y., 2009. "Re-Examining the Financial Development and Economic Growth Nexus In Kenya." Economic Modelling, 26(6):1140-1146. https://doi.org/10.1016/i.econmod.2009.05.002

World Bank 2007. "Making Finance Work for Africa" The International Bank for Reconstruction and Development/The World Bank. Available at: www.worldbank.org

$\mathrm{Xu}$, Z., 2000. "Financial Development, Investment and Economic Growth", Economic Inquiry, 38(2): 331-344. https://doi.org/10.1111/j.1465-7295.2000.tb00021.x

Zivot, E. and Andrews, D.W.K., 1992. "Further Evidence of the Great Crash, the oil-Price and the Unit-Root Hypothesis," Journal Of Business And Economics Statistics, 10(3): 251-270. https://doi.org/10.1080/07350015.1992.10509904

Received on 02-01-2017

DOI: https://doi.org/10.6000/1929-7092.2017.06.03

(c) 2017 Umar Bida Ndako; Licensee Lifescience Global.

This is an open access article licensed under the terms of the Creative Commons Attribution Non-Commercial License (http://creativecommons.org/licenses/by-nc/3.0/) which permits unrestricted, non-commercial use, distribution and reproduction in any medium, provided the work is properly cited. 